\title{
Counselling Strategies for Curbing Examination Malpractices in Secondary Schools in Enugu State, Nigeria
}

\author{
Anthonia Chinonyelum Egbo ${ }^{1, *}$ \\ ${ }^{1}$ Department of Guidance and Counselling, Faculty of Education, Enugu State University of Science and \\ Technology(ESUT), Enugu, Nigeria \\ *Correspondence: Department of Guidance and Counselling, Faculty of Education, Enugu State University of \\ Science and Technology(ESUT), Enugu, Nigeria. E-mail: egbononye@yahoo.com
}

Received: March 26, $2015 \quad$ Accepted: April 26, $2015 \quad$ Online Published: June 8, 2015

doi:10.5430/wje.v5n3p91 URL: http://dx.doi.org/10.5430/wje.v5n3p91

\begin{abstract}
This study investigated the Counselling strategies for curbing "Examination Malpractices" in Secondary Schools in Enugu State Nigeria. The researcher used three research questions. The Design used was a descriptive survey design. Sample consisted of 335 respondents comprising principals $(N=19)$, PTA secretaries $(N=19)$, teachers $(N=276)$ and Counsellors $(\mathrm{N}=21)$ selected through stratified random sampling. A researcher-developed questionnaire containing 27 items was validated by experts, subjected to reliability tests using Cronbach Alpha coefficient method to collect the data. Data was analyzed using mean ratings which revealed that out of the 27 proposed strategies investigated, the respondents agreed that 24 personal/social, educational and teachers' forum strategies will be useful in counselling students against examination malpractice in secondary schools in Enugu State. This means that unless several social, educational and teacher sensitization strategies are vigorously implemented, School counselling might not contribute much in the fight against Examination malpractice as one and evil practice in Secondary Education Sector. Recommendations included that Educational Management bodies, principals and PTA should sponsor and mount campaigns through the use of posters, bulletin boards, seminars and jingles to change student's attitude towards examination malpractices.
\end{abstract}

Keywords: concept of counselling strategies; examination malpractices; curbing

\section{Introduction}

According to the Nigerian National policy in education (2004), education has been identified as the major tool to achieve social, economic and industrial progress change and national integration in the country through the impartation of worthwhile knowledge and values into the young ones to cause them become functional members in the society. In Nigeria, secondary school education aims at preparing youths for effective and functional living in the society. But unfortunately, the realization of this aim is being threatened by the existence of evil practice called examination malpractice among students in secondary schools.

Examination in secondary schools is a very important tool used in the assessment of the academic performance of the students, which help to determine relevant courses of study to undertake in future. It helps both the teacher and the students to appreciate themselves. To the teacher, examination helps him determine how well and how far the knowledge imparted was assimilated by the students. On the other hand, examination provides opportunity for the student to critically assess himself on the course studied. Furthermore, examination helps to determine whether, the educational objectives set out in the school have been achieved (Nnabuike, 2013), He noted that in the past two decades, however, examination malpractices have been and continue to be on the increase in secondary schools in this area.

According to Nwanna (2006), he noted that it is worthy to observe that examination malpractices have since over the years caused a lot of grief to educational administration, law enforcement agents, examination bodies and the general public. The increase in the malpractice has led students to graduate as half baked secondary school graduates and to pursue courses of study, which they are not well equipped to study in the higher institutions of learning (Ukeje, 2008). He noted that they engage in several vices in the campuses like cultism, truancy and all sorts of juvenile delinquency because of their inability to cope. 
Also, most universities overseas are skeptical about admitting the graduating secondary school students due to the high incidence of the malpractices which has become a national problem in Nigerian schools. The Federal Government in a bid to reduce this ugly situation, which is about destroying education in the country, promulgated a decree stipulating a jail term of 21 years to every offender. Oladipo (2008), noted that malpractice takes many forms all geared to manipulating the results and covering their actual academic performance. They can engage in copying from their notebooks smuggled into the examination hall, bringing pieces of papers whose answers to the examination questions are written, hiring of mercenaries to write examination for them, bribing teachers and typists for examination question papers, bribing invigilators to allow them smuggle examination question papers and answers scripts, out of the examination hall e.t.c.

Egbo (2014) noted that the students equally manipulate examinations through the use of G S M phones. She stated that examination malpractice is a major problem in secondary schools in Enugu state as academic performances of students can no longer be passed confidently on the result of examination carried out by students.

Odo, (2014) writing on who cheats observed that neither the uncommitted attitude nor increase in the policing of examination halls will get at the causes, effects, motives and remedies, which are needed in order to reach the roots of the problem of cheating in classroom. He noted that examination malpractice in secondary schools has greatly increased.

The pressing issue at hand is how to find a lasting solution to the ugly incidence by introducing counselling strategies. Omorgie (2005) advocated the need to strategies that appeal to the conscience of the students in curbing examination malpractice. These include strategies such as guidance and counselling. Guidance and counselling is one of the educational support services provided in schools to help students manage their psychosocial and learning problems (Onyehalu, 2005). Iwuama (1999) sees counselling as a learning process in which individuals learn about themselves, their interpersonal relations and behaviours that advance their personal development. Counselling from this point of view entails a change in behavior after a person must have X-rayed himself, his interaction patterns with other people and his general way of life. Such self examination enables him to coin for himself the best way of conducting himself in the most socially acceptable manner. He learns about himself, other persons and his environment and uses such knowledge to develop the right attitudes and values within his social milieu. It is a method of helping the individual's positive strengths for development and by concentrating on the individual's personality behavioural and emotional assets that could be mobilized.Uba (2010), stated that to avoid disaster of examination malpractices, there is need for counselors who have the professional training with students to get the best out of them.

Oladele 2005 noted that the counselors use some counselling strategies to help the students build capacities and imbibe intrinsic beliefs about the importance of proper study habits, dedicated learning study habit, and dedicated learning, studying hard to pass their examinations and other positive human interactions needed to shun examination malpractices. Such strategies the counselor can use for effective change of attitudes are personal/social; vocational and educational strategies, hence the need for counselling strategies for curbing examination malpractices. The main purpose of this study is to find out those counselling strategies for curbing examination malpractices in Secondary Schools in Enugu State, Nigeria.

\section{Research Questions}

Three research questions were used for the purpose of this research work.

1) What personal counselling strategies will be useful in curbing examination malpractices in secondary schools in Enugu state, Nigeria?

2) What educational social counselling strategies will be used in curbing examination malpractices in Enugu state, Nigeria?

3) What teacher participation strategies will be useful in curbing Examination Malpractices in Secondary Schools in Enugu State, Nigeria?

\section{Research Design}

The study adopted a descriptive survey research. Nworgu, (2006) refers to survey as one which a group of people or items is studied by collecting and analyzing data from a few people or items considered to be representative of the group. This design is appropriate for this study because the study involved collecting and describing data obtained from a sample of a population in order to determine the strategies for counselling against "examination malpractices" 
among secondary school students in Secondary schools in Enugu State of Nigeria.

\section{Area of Study}

The study was carried out in secondary schools in Enugu state of Nigeria.

\section{Population of Study}

The population for the study comprised all the principals, teachers, counselors and secretaries of parents' teachers associations (PTA) in Enugu state Nigeria because of their direct contact with the students and thereby hold key positions in influencing students in engaging in examination conduct. According to the available data from the post primary schools management board (PPSMB) there are 38 principals, 38 PTA secretaries, 1088 teachers and 41 counsellors in secondary schools in Enugu education zones of Enugu state Nigeria. Therefore, the population for the study comprises 1205 respondents.

\section{Sample and Sampling Technique}

Stratified random sampling technique was used to sample 335 respondents used for the study. The stratification was based on school location (Enugu North, Enugu south and Enugu East). From each of the locations, 50 percent of the schools were randomly selected. Then all the principals $(\mathrm{N}=19)$, P.T.A secretaries $(\mathrm{N}=19)$ teachers $(\mathrm{N}=276)$ and counsellors $(\mathrm{N}=21)$ were selected from the population making it 335 respondents.

\section{Instrument for Data Collection}

Questionnaire was the main instrument used in collecting information for this study. The questionnaire is titled "Counselling Strategies against Examination malpractices among Students (CSEMAS)." The questionnaire has two parts. Part A sought information on the respondents' personal information while part B consisted of twenty eight (28) item questions sub divided into 3 parts A, B and C. section A consisted of ten items on the educational counselling strategies, section B consisted of eight items on socio/personal counselling strategies while section C consisted of ten items on --- vocational counselling strategies. The responses to the questionnaires items were designed on a four point scale of measurement. Thus;

Strongly Agree (SA): 4 points

Agree (A): 3 points

Disagree (DS): 2 points

Strongly Disagree (SD) 1 point

Mean ratings above 2.50 is regarded acceptable while below 2.50 is rejected.

\section{Validation of Instrument}

The research instrument was face validated by three experts' one in measurement and evaluation while two are in Guidance and Counselling, all in the faculty of education. The experts were told the purpose of the study and asked to equally evaluate the appropriateness of the language used. The corrections given were effected for the final modification of the items of the questionnaires.

\section{Reliability of the Instrument}

To test the reliability of the instrument, the researcher administered the instrument on a sample of 5 principals, 10 teachers, 3 PTA secretaries and 3 Counsellors from Ebonyi education zone of Ebonyi state of Nigeria. The responses were analyzed using Cronbach Alpha, reliability coefficient values of 0.94, 0.89 and 0.93 were obtained indicating the reliability of the instrument.

\section{Method of Data Collection and Analysis}

The researcher with the help of four trained research assistants distributed the questionnaires to the respondents and collected them on the spot. 329 copies of the questionnaires were collected and used for the study. This is because 4 teachers and 2 PTA secretaries failed to submit their questionnaires. 


\section{Data Presentation}

Research question 1: what Socio/personal counselling strategies will be useful in curbing examination malpractices among secondary school students in Enugu state Nigeria?

Table 1. Respondents' Mean Ratings of the Personal/Social Counselling Strategies That Will be Useful in Curbing 'Examination Malpractices' among Secondary School Students

\begin{tabular}{|c|c|c|c|c|c|}
\hline \multirow[t]{2}{*}{$\mathbf{S} / \mathbf{N}$} & \multirow[t]{2}{*}{ PROPOSED STRATEGY } & \multicolumn{4}{|c|}{ MEAN RESPONSE } \\
\hline & & PR & PTA & TRS & CLLS \\
\hline 1 & $\begin{array}{l}\text { Developing warm relationship with students to help a counselor know } \\
\text { when a student is no longer interested in school affairs. }\end{array}$ & 4.00 & 4.00 & 3.38 & 3.68 \\
\hline 2 & Praising students' academic efforts to boost their academic self-concept. & 3.51 & 3.89 & 3.98 & 3.76 \\
\hline 3 & $\begin{array}{l}\text { Showing affection and heart-felt concern to students to enable them open } \\
\text { up with their learning and peer problems. }\end{array}$ & 3.55 & 3.42 & 3.45 & 3.68 \\
\hline 4 & $\begin{array}{l}\text { Mandating students to declare through signed under-takings or sworn } \\
\text { affidavits that they will not engage in "Examination Malpractices" or be } \\
\text { ready to face expulsion if they do. }\end{array}$ & 1.49 & 3.46 & 1.22 & 1.00 \\
\hline 5 & $\begin{array}{l}\text { Counsellors should keep appropriate records of students' enrolment, } \\
\text { cumulative performances during and after exams to help to track down } \\
\text { students that engage in exam malpractices. }\end{array}$ & 3.95 & 3.00 & 3.00 & 3.45 \\
\hline 6 & $\begin{array}{l}\text { Announcing names of students that engage in examination malpractice } \\
\text { during test and examinations at morning assembly before inviting them } \\
\text { to counsellor's office. }\end{array}$ & 1.55 & 1.87 & 1.92 & 1.24 \\
\hline 7 & $\begin{array}{l}\text { Giving students awards for termly performances to make them } \\
\text { committed to learning. }\end{array}$ & 3.00 & 2.89 & 3.12 & 3.64 \\
\hline 8 & $\begin{array}{l}\text { Examination ethics and values should be incorporated into the morning } \\
\text { assembly manuals of schools. }\end{array}$ & 3.95 & 3.00 & 3.00 & 3.45 \\
\hline
\end{tabular}

Table 1 reveals that only items 4 (Mandating students to declare through signed under-takings or sworn affidavits that they will not engage in "examination malpractice" or face expulsion if they do) and 6 (Announcing names of students that engaged in examination malpractice at morning assembly before inviting them to counsellor's office) were rated below the acceptance mean level of 2.50 by all categories of respondents. The rest of the proposed strategies had mean ratings above 2.50 indicating the agreement of principals, teachers, PTA secretaries and counsellors that apart from items 4 and 6 , all the other proposed strategies should be adopted to a great extent in counselling against "examination malpractice" in secondary schools in Enugu State.

Research question 2: What educational counselling strategies will be useful in curbing "Examination Malpractices" among secondary school students?

In the table 2, only item 14(Every school should organize extra moral classes after school hours to steer students' interest away from "Examination Malpractices was rated below 2.50 by all respondents. The rest of the items had mean ratings above 2.50 . This means in the respondents' opinion, apart from item 14, the other educational strategies listed should be adopted in counselling students against "Examination Malpractices". 
Table 2. Respondents Mean Ratings of the Educational Counselling Strategies That Will be Useful in Curbing "Examination Malpractices" among Secondary School Students

\begin{tabular}{|c|c|c|c|c|c|}
\hline \multirow[t]{2}{*}{$\mathbf{S} / \mathbf{N}$} & \multirow[t]{2}{*}{ ITEMS PROPOSED STRATEGY } & \multicolumn{4}{|c|}{ MEAN RESPONSE } \\
\hline & & PR & $\begin{array}{l}\text { PTA } \\
\end{array}$ & TRS & CLLS \\
\hline 9 & $\begin{array}{l}\text { Students should be constantly exposed to quiz and reading competitions } \\
\text { to enable them cultivate reading habits. }\end{array}$ & 3.72 & 3.64 & 3.47 & 3.95 \\
\hline 10 & $\begin{array}{l}\text { Provision should be made in schools timetable for counselling periods, } \\
\text { where counsellors can discuss learning problems and offer solutions for } \\
\text { students. }\end{array}$ & 2.96 & 3.00 & 2.97 & 3.22 \\
\hline 11 & $\begin{array}{l}\text { Teachers should monitor students' classroom progress, refer those with } \\
\text { learning difficulties for counselling services and provide unrestricted } \\
\text { information on student to guidance counsellors. }\end{array}$ & 3.60 & 3.56 & 3.70 & 3.47 \\
\hline 12 & $\begin{array}{l}\text { Bulletin boards and handbills should be erected in strategic positions in } \\
\text { schools to facilitate students' internalization of moral values. }\end{array}$ & 3.00 & 3.45 & 3.56 & 3.88 \\
\hline 13 & $\begin{array}{l}\text { Counsellors should use child-friendly strategies to encourage students to } \\
\text { study hard and read manuals on all consequences of examination } \\
\text { malpractice. }\end{array}$ & 2.96 & 2.94 & 2.97 & 2.94 \\
\hline 14 & $\begin{array}{l}\text { Every school should organize extra moral classes after school hours to } \\
\text { steer students' interest away from "Examination Malpractices" }\end{array}$ & 1.67 & 1.34 & 1.22 & 1.45 \\
\hline 15 & $\begin{array}{l}\text { Parents should be more involved in students' school behaviors and issues } \\
\text { in students' engagement with "Examination Malpractices" should always } \\
\text { be discussed during PTA meetings. }\end{array}$ & 3.56 & 3.66 & 3.55 & 3.47 \\
\hline 16 & $\begin{array}{l}\text { Counsellors should conduct orientation programmes on examination } \\
\text { ethics and values for students at the beginning of every term from Junior } \\
\text { classes to senior classes. }\end{array}$ & 3.56 & 3.66 & 3.55 & 3.47 \\
\hline 17 & $\begin{array}{l}\text { Seminars, jingles and symposium should be organized to explain to } \\
\text { students the dangers in seeking certificates in lieu of functional learning. }\end{array}$ & 3.00 & 3.07 & 3.23 & 3.98 \\
\hline
\end{tabular}

Research Question 3: To what extent will counselling of staff be useful in curbing "Examination Malpractices" in secondary schools in Enugu State of Nigeria.

Table 3. Mean Ratings of Respondents on Strategies for Counselling Staff Against "Examination Malpractices" in Secondary Schools in Enugu State Nigeria(to be continued)

\begin{tabular}{|c|c|c|c|c|c|}
\hline \multirow[t]{2}{*}{$\mathbf{S} / \mathbf{N}$} & \multirow[t]{2}{*}{ PROPOSED STRATEGY } & \multicolumn{4}{|c|}{ MEAN RESPONSE } \\
\hline & & PR & PTA & TRS & CLLS \\
\hline 19 & $\begin{array}{l}\text { Teachers should be counseled to motivate and reinforce student's } \\
\text { positive classroom behaviours especially good conducts after exams. }\end{array}$ & 3.50 & 3.76 & 3.70 & 3.77 \\
\hline 20 & $\begin{array}{l}\text { Seminars and workshops should be organized for teachers to help } \\
\text { them learn to clarify their values and shun involvement in } \\
\text { "Examination Malpractices". }\end{array}$ & 3.56 & 3.57 & 3.56 & 3.55 \\
\hline 21 & $\begin{array}{l}\text { Counsellors should mentor teachers so as to encourage them } \\
\text { understand and manage differences in abilities and needs of students } \\
\text { and channel them against pursuit of certificates. }\end{array}$ & 3.56 & 3.66 & 3.44 & 3.47 \\
\hline 22 & $\begin{array}{l}\text { Staff forum should be made more responsive to teacher-students' } \\
\text { discipline problems. This will enable staff brainstorm and become } \\
\text { positively oriented to fighting all forms of examination malpractices. }\end{array}$ & 3.86 & 3.80 & 3.00 & 2.72 \\
\hline 23 & $\begin{array}{l}\text { Staff should be encouraged to join and mentor students in their } \\
\text { various clubs to fully integrate them into the mainstream of students' } \\
\text { extracurricular affairs. }\end{array}$ & 3.70 & 3.51 & 3.89 & 3.18 \\
\hline
\end{tabular}


Table 3. (Continued)

\begin{tabular}{|c|c|c|c|c|c|}
\hline 24 & $\begin{array}{l}\text { Basic tips on counselling handbook should be published for teachers' } \\
\text { use to improve teachers' capacities in counselling students against } \\
\text { "Examination Malpractices". }\end{array}$ & 3.22 & 3.20 & 3.24 & 3.22 \\
\hline 25 & $\begin{array}{l}\text { Principals should set up operational task force at school level, } \\
\text { comprising teachers and counselors, and charge them with evolving } \\
\text { psychological means of refocusing students in school affairs. }\end{array}$ & 3.22 & 3.20 & 3.21 & 3.22 \\
\hline 26 & $\begin{array}{l}\text { Teachers should be motivated through adequate incentives, to } \\
\text { develop interest in students' counselling and show empathy to } \\
\text { students, so that they will be able to predict and intervene in students' } \\
\text { intention to get involved in "Examination Malpractices". }\end{array}$ & 3.74 & 3.80 & 3.46 & 3.49 \\
\hline 27 & $\begin{array}{l}\text { Counsellors should be relieved of teaching tasks to give enough time } \\
\text { to talk to the teachers on how to direct students on how to pursue } \\
\text { their academic ambitions. }\end{array}$ & 1.70 & 1.89 & 1.40 & 2.10 \\
\hline 28 & $\begin{array}{l}\text { Parents should motivate and recognize form teachers by sending } \\
\text { students to them for help in filling their JAMB and WAEC forms. }\end{array}$ & 3.00 & 3.00 & 2.98 & 3.02 \\
\hline
\end{tabular}

In table 3, only item 27 (counselors should be relieved of teaching tasks to give them ample time to monitor students, and direct them in their academic pursuits) was rated below 2.50 by all respondents. The rest of the items had mean ratings above 2.50. This means in the respondents' opinion, apart from item 27, the other strategies listed should be adopted in enhancing teacher participation in counselling students' against "Examination Malpractices".

\section{Discussion of Findings}

From the respondents' mean ratings to the research questions for this study, one can see that they agreed that providing interactive group counselling to students, referring students for counselling services and providing unrestricted information to guidance counselors are necessary. Also, they agreed that provision of bulletin boards and handbills to enable students internalization of moral values, using child-friendly strategies to probe into learning problems and advising students against all forms of examination malpractice, motivating counselors to conduct orientation programmes on examination ethics and values for students, should be adopted in counselling students against "Examination Malpractices". In addition, Principals should set up operational task force at school level, comprising teachers and counselors, and charge them with evolving psychological means of refocusing students in school affairs. Teachers should be motivated through adequate incentives, to develop interest in students' counselling and show empathy to students, so that they will be able to predict and intervene in students' tendency to engage in "Examination Malpractices".

However, the respondents disagreed on the announcement of the names of students that engaged in examination malpractices at morning assembly while inviting them to the counsellor's office and relieving counselors of teaching tasks to give them enough time to monitor students and direct them in their academic pursuit. They also disagreed that providing for counselling periods in schools timetable and mandating students to declare through signed under-takings or sworn affidavits that they will not engage in "examination malpractice" or face expulsion if they do, are counselling strategies for counselling against "Examination Malpractices".

These findings are welcome developments because they show that principals, teachers, PTA secretaries and counselors themselves appreciate the fact that the roles of the guidance counselors in educational endeavors make them important participants in the fight against students involvement in "Examination Malpractices". Therefore much is expected from school counselors in providing interactive group counselling to students and using child-friendly strategies to probe into learning problems and advising students against all forms of examination malpractices. These would help in nurturing students to develop positive attitudes towards in-school external examination. Uba (2010) was of the opinion that the guidance of students' interests, attitudes, activities and future aspirations environment is of crucial importance to steering students away from undisciplined conduct.

The performance of these roles however requires that both teachers and counselors be provided with management support such as recognition from parents, seminars and workshops, support supervisions and other capacity building incentives, as shown by responses to research question three. Collaboration partnerships with principal, teachers and 
counselors are needed. This finding is in line with the findings of Ifelumni, 2005), which reveals that the "current inhibitive environment of counselling in secondary schools" (might only worsen the problem of students' interest in examination malpractice. In many schools, collaboration partnerships between counselors and principals do not exist. Counselors are not given due recognition and this hinders them from performing their counselling roles effectively. In some other schools, the counselors are almost redundant, as if their services are not recognized or needed.

\section{Recommendations}

The following recommendations are made based on the findings:

1. Principals and school supervisors should make school supervision and standards monitoring more supportive in order to ensure that school activities facilitate positive value-orientation and sustain students' interest in school based examinations.

2. Guidance counsellors should be recognized, motivated, empowered and given the opportunity to offer the valuable services needed form effective management and eradication of students' involvement in examinations malpractice.

3. Educational management bodies, principals and PTA should sponsor and mount campaigns through billboards, handbills, seminars and jingles to modify student's attitudes to "examination malpractice" and emphasize the value of hard work for success.

4. Teachers should see counselors as partners in progress and collaborate with them in counselling students against "examination malpractices".

5. Capacity-building opportunities should be provided for teachers and counselors to improve their counselling capabilities in students' social and educational guidance. Handbook on basic tips on counselling should be published for teachers' use.

6. Students, teachers and parents should be sensitized through media jingles to understand that education is not all about passing examinations at all costs.instead education is about gaining useful knowledge and skills for personal and societal productivity and that this can never be achieved through "examination malpractices".

\section{Implication of the Findings and Conclusion}

What the findings of this study imply is that several social, educational and staff forum strategies will be useful and unless the strategies identified in this study are vigorously implemented; school counselling might not contribute much in the fight against "examination malpractices" as one of the corrupt practices in the secondary education sector. In conclusion therefore, counselors, principals, parents and teachers have roles to play in counselling against students' involvement in "examination malpractices". Principals should recognize the indispensable roles of counselling to school development and the counsellors should sit up and display appreciable levels of resourcefulness and competence in counselling students not only against "examination malpractices" but also other vices in the school system and also help them on how to develop vocational interests.

\section{References}

Egbo, A. C. (2013). Development of Guidance and Counselling. Enugu: Agada Prints.

Federal Republic of Nigeria (2004). National Policy on Education. Lagos: NERDC.

Ifelumni, I. (2005). The Missing Link in Nigerian Education System. A keynote Presented at the Conference on the State of Education in Nigeria, Held at Federal College of Education (Technical) Asaba, On $13^{\text {th }}$ June 2005.

Iwuama, B. C. (1999). Foundations of Guidance \& Counselling. Imo: Joe Mankpa Publishers.

Nnabuike, E. K. (2013). Practical Guide to Effective Teaching. Enugu: Hallmark Publishers.

Nwanna, O. C. (2006). Major School Offences in Nigeria Ikenga. Journal of African Studies in University of Nigeria Nsukka Campus, 1(2), 66-75.

Nworgu, B. C. (2006). Educational Research, Basic Issues and Methodology. Enugu: University Trust publishers.

Odo, J. (2014). Who and who Cheats during Examination. A paper presented at the Orientation of newly admitted students Enugu State University of Science and Technology (ESUT), Auditorium on $24^{\text {th }}$ January 2004. 
Oladele, J. O. (2005). Fundamentals of Psychological Foundations of Education. Lagos: John- Lad Publishers Ltd.

Oladipo, T. (2008). When Teachers Aid Cheating, Guardian News paper 2009 August, 11, p.7.

Omorgie, N. (2005). Irregular trends in students' enrolment for terminal Examinations in Edo State of Nigeria. Implications for Educational standards in secondary schools. Paper presented at a conference on the state and future of education in Nigeria. Held at Technical college Asaba on $13^{\text {th }}$ June 2005.

Onyehalu, M. T. (2005). The place of Guidance and Counselling in personal Development. Journal of Counselling and communication, 1(2), 58-60.

Ubah, M.S. (2010). Disasters in Education. Abia: Maryland Publishers.

Ukeje, B. O. (2008). Educational Administration: Theory and Practice. Abuja. Totan Man Publishers Limited. 